\title{
SV40形質転換ラット前立腺背側葉細胞株の研究
}

一上皮細胞株の成長因子と成長因子受容体に関する検討一

\author{
広島大学医学部泌尿器科学教室* (主任：碓井 亞教授) \\ 田 丁 貴 俊
}

\section{STUDY OF SV40-TRANSFORMED CELL LINES FROM RAT DORSOLATERAL PROSTATE}

-Analysis of Growth Factors and their Receptors in the Epithelial Cell Line-

Takatoshi Tacho

Department of Urology, Hiroshima University, School of Medicine, Hiroshima (Director: Prof. T. Usui)

(Background) We transformed primary cultured epithelial cells of the rat dorsolateral prostate by Simian Virus 40 (SV 40) and established a stable epithelial cell line (PESVH). To examine whether this cell line is available for the fundamental research of prostatic diseases, investigation on the growth factors and their receptors of this cell line was made.

(Method) The $\left[{ }^{3} \mathrm{H}\right]$-thymidine uptake method was used to examine the influence for cell proliferation of epidermal growth factor (EGF), acidic fibroblast growth factor (aFGF), basic fibroblast growth factor (bFGF), keratinocyte growth factor (KGF), transforming growth factor (TGF)- $\alpha$, TGF- $\beta 1$ and androgens. The expression of mRNA for growth factors and their receptors was determined with Northern blot analysis.

(Result) DNA synthesis was increased to 2.1-fold of control by the addition of $100 \mathrm{ng} / \mathrm{ml} \mathrm{EFG}$. The addition of aFGF (100 ng/ml), bFGF (100 ng/ml) and TGF- $\alpha(100 \mathrm{ng} / \mathrm{ml})$ tended to stimulate the DNA synthesis, but not significantly. The addition of $\mathrm{KGF}(0.1-100 \mathrm{ng} / \mathrm{ml})$ did not influence on the DNA synthesis of PESVH. The addition of testosterone and $5 \alpha$-dihydrotestosterone $\left(10^{-10}\right.$. $\left.10^{-6} \mathrm{M}\right)$ did not influence on the DNA synthesis. Northern blot analysis showed expression of mRNA for TGF- $\alpha$, TGF- $\beta 1$, EGF receptor and TGF- $\beta$ receptor (type II) in PESVH cell. These expressions were not influenced by the addition of androgens.

(Conclusion) These findings suggested that PESVH cell could be used for one model of the androgen-independent prostatic cell.

Key words: rat prostate, transformed epithelial cell, growth factors

要旨：(目的）SV40を用いてラット前立腺背側葉初代培養上皮細胞を形質転換し，安定な上皮細胞株 (PESVH) を樹立した，前立腺疾患の基礎的検討における本細胞株の特性をみるため，成長因子および その受容体について検討した.

（方法） $\left[{ }^{3} \mathrm{H}\right]$-チミジン取り込み法によるDNA 合成活性を指標として EGF，aFGF，bFGF，KGF， TGF- $\alpha$ ，TGF- $\beta 1$ およ゙゙アンドロゲン添加の影響を検討した。 また，PESVH 細胞から poly (A) RNA を抽出, 精製し, EGF, bFGF, KGF, TGF- $\alpha$, TGF- $\beta 1$, EGFR, FGFR1およびTGF- $\beta$ R(Type II) mRNA 発現の有無, アンドロゲン添加の影響についてノーザンブロット法を用いて検討した

(結果) 各種濃度の aFGF，bFGF，KGF，TGF- $\alpha ，$ TGF- $\beta 1$ にる細胞増殖に対する効果は有意では

*現 松山赤十字病院泌沓器科 


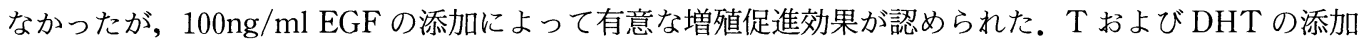
はこの細胞の増殖に影響しなかった。また，TGF- $\alpha$, TGF- $\beta 1$, EGFR およびTGF- $\beta$ R (type II) の mRNA がそれぞれ発現しており，これらの発現はアンドロゲン添加の影響を受けなかった。

(結論) PESVH 細胞は, アンドロゲン非依存性前立腺細胞のひとつのモデルとなりうると考えられた. キーワード：ラット前立腺, 形質転換上皮細胞, 成長因子

\section{緒 言}

前立腺は，加齢とともに高率に増殖性疾患（前立腺 肥大症および癌）をきたし，急速な高齢化が進む我が 国においては重要な臟器のひとつと考えられる。特に 前立腺癌は臨床上進行例が多く，このような進行例に 対する治療の主体は今日でも抗男性ホルモン療法であ る.しかし，この抗男性ホルモン療法は初期効果は期 待できるが，中，長期的な経過中に過半数の症例は再 燃をきたし，再燃後の有効な治療法は確立していない のが現状である。この問題を検討するための基礎的な 実験モデルとして, ラット前立腺の上皮細胞培養法は 有用な手段の一つと考えられる.

一方, ラット前立腺は腹葉と背側葉からなるが, 背 側葉は腹葉と比較して細胞内亜鉛濃度 ${ }^{1)}$, 加齢に伴う 肥大傾向 ${ }^{21}$, 自然発生癌の存在 ${ }^{3)}$, 解剖学的位置などの 点に関してヒト前立腺との類似性が高い。この前立腺 背側葉上皮細胞の初代培養法を用いた検討) 7) におい ては，アンドロゲンは細胞増殖促進作用を示さない ${ }^{5) 6}$ が，上皮成長因子 (EGF) は対照の約10倍の增殖促進 効果を ${ }^{6)}$, また, 酸性線維芽細胞成長因子 $(\mathrm{aFGF})$, 塩 基性線維芽細胞成長因子 (bFGF) は明らかな増殖促進 を示し7), また, transforming growth factor(TGF) $-\beta$ は前立腺上皮細胞の増殖を逆に抑制する7)。このよう に前立腺上皮細胞の初代培養は前立腺における成長因 子の研究において優れた方法である.

しかし, 初代培養細胞では細胞の増殖能は徐々に低 下し，7日から10日で細胞数は減少し始めるという久 点がある ${ }^{4) 8}$. また，安定して細胞を得るには手技的に も習熟の必要がある。そこで，長期間にわたり安定し た性状の上皮細胞を得るため, Nakahara ら ${ }^{91}$ は simian virus 40 （SV40）を用いて，ラット前立腺背側葉 上皮初代培養細胞を形質転換し安定な細胞株 (PESVH 細胞)を樹立した。この細胞株は上皮細胞と しての基本的な特性を有しているが, さらにこの細胞 株の特性を明らかにし, 前立腺疾患の基礎的研究にお ける有用性をみるため, 細胞成長因子の要求性, その 産生能および受容体の有無について検討した。

\section{方 法}

1. 継代細胞培養法

PESVH 細胞の継代培養法は Nakahara ら ${ }^{9}$ の方法 に準じた。すなわち，WAJC404培地(極東製薬，東京) に 2 \%仔牛血清 (CS : Flow Laboratory, Inc., Irvine, Scotland), 2.5nM マウス EGF (東洋紡, 東京), 120 $\mathrm{pM}$ コレラ毒素(生化学工業, 東京), 650nM インシュ リン (Sigma, Inc., St. Louis, USA), 300nM デキ サメサゾン(和光純薬, 大阪) および蛋白濃度 $25 \mu \mathrm{g} / \mathrm{ml}$ の下垂体抽出液（極東製薬）を添加したものを完全培 地として継代培養した。

培養は $37^{\circ} \mathrm{C}, 5 \% \mathrm{CO}_{2}, 95 \%$ 空気中で行い, 培地交換 は 3 日ごとに行った. 定常期の細胞を $0.02 \%$ リプシ ン(Gibco, Inc., Gettysburg, USA)/0.1\%EDTA 溶 液で洗浄, 遊離させた。この遊離細胞を $2 \% \mathrm{CS}$ 加 WAJC404培地中で遠心, 1：4 亿希釈し, 継代した.

2. 各種成長因子およびアンドロゲン要求性の検討

$\left[{ }^{3} \mathrm{H}\right]$-チミジン取り込み法による DNA 合成活性を 指標として, 0.1〜 100ng/ml の EGF, $\mathrm{aFGF}$ (東洋紡), bFGF (東洋紡), Keratinocyte growth factor (KGF ; Promega Corp., Madison, USA), TGF- $\alpha$ (コスモ バイオ, 東京), TGF- $\beta 1$ (キング醇造, 倉敷), $10^{-10}$ $\sim 10^{-6} \mathrm{M}$ のテストステロン ( $\mathrm{T}$; Sigma, Inc.) あるい は $5 \alpha$-ジヒドロテストステロン (DHT ; Sigma, Inc.) の添加が PESVH 細胞の増殖に与える影響について 検討した。すなわち24穴プラスチックプレート（住友 ベークライト，東京）に PESVH 細胞を播種 $\left(2 \times 10^{4}\right.$ cells/well), 前述の完全培地にて 2 日間培養後, 血清 および各種成長因子をすべて除いた WAJC404培地に 交換した。 3 日間培養後, 被検成長因子あるいはアン ドロゲンを加えた培地に交換,さらに24時間培養した。 ついで $1 \mu \mathrm{Ci} /$ well のメチル- $\left[{ }^{3} \mathrm{H}\right]$-チミジン $(\mathrm{NEN}$ DuPont, Inc., Wilmington, USA)を添加し，3時間 後にその搨取率を測定, DNA 合成活性の指標とした. 測定はすべて 3 重測定で 2 回の実験を行い, 各種成長 因子あるいはアンドロゲン非添加時の測定值を対照と した相対値で示した。統計学的検討は Kruskal-Wallis 検定および Dunnett の多重比較検定を用いた。 
3. 細胞成長因子およびその受容体 mRNA 発現の 検討

A. mRNA 抽出法

Total RNAの抽出には acid guanidinium thiocyanate-phenol-chloroform 法得を用いた。完全培 地あるいは完全培地中に $10^{-8} \mathrm{M}$ の $\mathrm{T}$ または DHT 存 在下で培養した PESVH 細胞について, RNA 単離試 薬 ISOGEN（ニッポンジーン，東京） $1 \mathrm{ml} / 10^{6}$ cells を 用いて total RNA を抽出した. poly（A）RNAの精 製にはポリATトラクト mRNA アイソレーションシ ステム (Promega Corp.) を用いた。

B. ノーザンブロット法

（1）電気泳動法およびブロット法

$6 \%$ ホルムアルデヒド含有 $1 \% \mathrm{GTG}$ アガロースゲ ル (FMC Bioproduct Corp., Rockland, USA) を用 い, poly (A) RNA $2 \mu \mathrm{g} /$ lane (loading buffer ; $1 \mathrm{mM}$ EDTA, $0.25 \%$ bromophenol blue, $0.25 \%$ xylene cyanol, $50 \%$ glycerol) を $50 \mathrm{~V}$ で 2 時間, 電気泳動した. その poly (A) RNA を55mbar. の陰圧によってナイロ ン膜に移行させ (Vacu Gene システム, Pharmacia Corp., Uppsala, Sweden), 紫外線 $\left(0.25 \mathrm{~J} / \mathrm{cm}^{2}\right) に$ て固定した.

（2）Hybridization 法および検出法

EGF, bFGF, KGF, TGF- $\alpha$, TGF- $\beta 1$, EGF 受容 体 (EGFR), FGF 受容体 1 (FGFR1) および TGF $\beta$ 受容体 type II (TGF $\beta$ R2) mRNA について, それ ぞれの cDNA をジゴキシゲニンーdUTP (ノンラジオ システムDNA 標識および検出キット; Boeringer Mannheim Corp. Indianapolis, USA）で標識したも のをプローブとして用いた ${ }^{11)}$. $65^{\circ} \mathrm{C} て ゙ 16 〜 18$ 時間八イ ブリダイズさせた後，アルカリホスファターゼ標識抗 ジゴキシゲニン抗体（キットに付属）を室温にて，30 分間反応させた．その後, 化学発光基質 (Lumi-phos 530 ; 和光純薬) を噴霧し, 室温で X 線フィルム（コ ダック XRP-5）に感光させ mRNA を検出した. 検出 結果はイメージスキャナー（HP Scan Jet 3c；横河・ ヒューレット・パッカード，東京）を用いてデジタル 化し, 画像解析を行った. control gene としてはグリ セルアルデヒド三リン酸脱水素酵素 (GAPDH) mRNA を用いた。

\section{結 果}

1. EGF, FGFs 添加による DNA 合成活性への影響 (Fig. 1).

$\mathrm{EGF}$ は0.1ng/ml から100ng/ml まで添加濃度の増
Fig. 1 Effects of growth factors (aFGF, bFGF, $\mathrm{KGF}, \mathrm{EGF})$ on the $\left[{ }^{3} \mathrm{H}\right]$-thymide uptake-rate of PESVH cells.

aFGF (O), bFGF ( $\square)$, KGF (○) and EGF were added to the medium in $0.1 \sim 100 \mathrm{ng} / \mathrm{ml}$, and $\left[{ }^{3} \mathrm{H}\right]$-thymidine uptake-rate were measured as described under Methods. The relative value to the control are displayed in the graph. Vertical bars represent means \pm SD. ${ }^{*}: \mathrm{p}<0.05$.

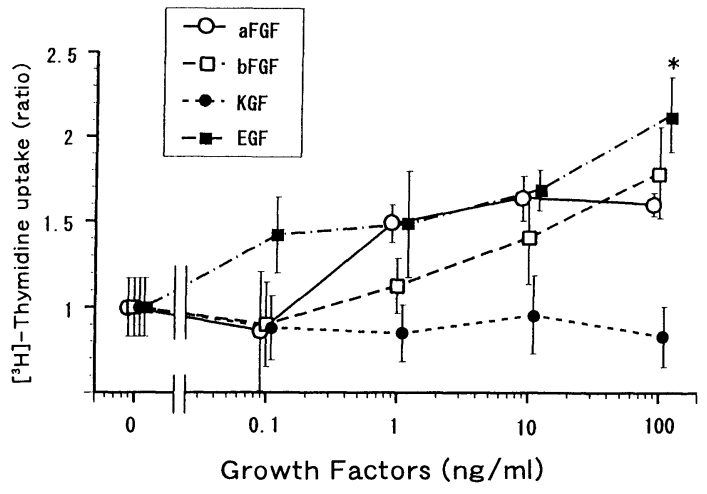

加に応じて DNA 合成の促進がみられ, $100 \mathrm{ng} / \mathrm{ml}$ 添加 では対照の $210 \%$ 有意な DNA 合成促進を示した $(\mathrm{p}<0.05) . b F G F$ も同様に添加濃度の増加によって DNA 合成の促進傾向がみられたが，有意なものでは なかった $(\mathrm{p}=0.224) . \mathrm{aFGF}$ では $10 \mathrm{ng} / \mathrm{ml}$ 以上の添加 でDNA 合成活性促進傾向がみられたが，有意ではな かった $(\mathrm{p}=0.333) . \mathrm{KGF}$ は今回の条件では有意な DNA 合成促進あるいは合成抑制のいずれの作用も示 さなかった $(\mathrm{p}=0.458)$. 以上の結果は 2 回の実験で同 様の傾向を示した。

2. TGF 添加による DNA 合成活性への影響（Fig. 2)

TGF- $\alpha$ は添加濃度の増加につれて DNA 合成の促 進傾向を示したが有意なものではなかった（ $\mathrm{p}=$

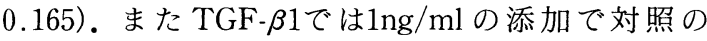
$80 \%$ まで DNA 合成が抑制されたが，有意ではなかっ た $(\mathrm{p}=0.268)$.これらの結果は 2 回の実験とも同様の 傾向で，変動の大きいほうを図示した。

3.アンドロゲン添加による DNA 合成活性への影 響 (Fig. 3)

$10^{-10} \sim 10^{-6} \mathrm{M}$ の $\mathrm{T}$ お にそれぞれ添加したが，いずれの添加濃度においても 有意な DNA 合成促進あるいは合成抑制は認められな かった $(\mathrm{T} ; \mathrm{p}=0.255, \mathrm{DHT} ; \mathrm{p}=0.448)$.さらに, 完 
Fig. 2 Effects of growth factor (TGF- $\alpha$ and TGF$\beta 1$ ) on the $\left[{ }^{3} \mathrm{H}\right]$-thymidine uptake-rate of PESVH cells.

TGF- $\alpha(\square)$ and TGF- $\beta 1$ ( ) were added to the medium in $0.1 \sim 100 \mathrm{ng} / \mathrm{ml}$, and $\left[{ }^{3} \mathrm{H}\right]$-thymidine uptake-rate were measured. The graph was charted similar to figure 1.

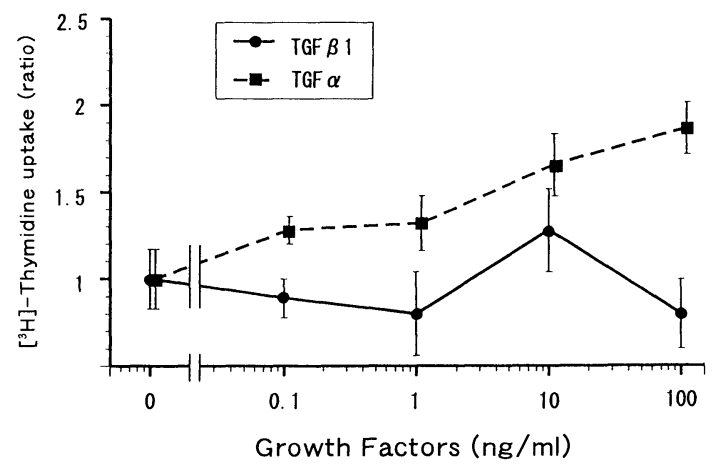

Fig. 3 Effects of androgen on the $\left[{ }^{3} \mathrm{H}\right]$-thymidine uptake-rate of PESVH cells.

Testosterone $(\mathrm{T}: \mathbf{O})$ and $5 \boldsymbol{\alpha}$-dihydrotestosterone (DHT: $\square$ ) were added to the medium in $10^{-10}$ $\sim 10^{-6} \mathrm{M}$. The graph was charted similar to figure 1 .

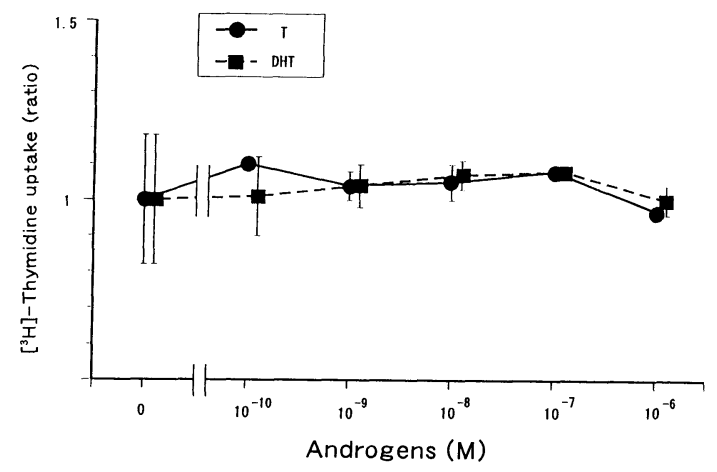

全培地に T および DHTを添加した条件下でも同様 な成績であった。

4. 各種成長因子およびその受容体の mRNA 発現 の検討 (Fig. 4)

成長因子としては TGF- $\alpha, T G F-\beta 1$ mRNA の発現 を認めたが, いずれの成長因子 mRNA の発現強度も, GAPDHmRNAの発現の程度と比較するとアンドロ ゲン添加による明らかな変化は認められなかった。 $\mathrm{EGF}, \mathrm{bFGF}, \mathrm{KGF}$ については今回検討した条件下で は発現がみられなかった。また，成長因子受容体では
EGFR，TGF- $\beta$ R2の mRNA が発現していたが，その 発現の程度には, GAPDHmRNA の発現の程度と比較 してアンドロゲン添加による変化は認められなかっ た.FGFR1は今回の条件では発現が認められなかっ た.

\section{考察}

Jacobs らがヒト前立腺癌組織抽出液中に胎児骨芽 細胞に対する増殖促進活性物質のあることを報告 ${ }^{12)}$ て以来, 前立腺由来成長因子の報告は数多くみられる。 EGF は in vitro では上皮系, 間葉系の細胞に対して増 殖促進作用を有し，前立腺細胞に対しても増殖促進効 果が認められる6). aFGF，bFGF は，ともに体内に広 く分布し，前立腺上皮細胞に対しても増殖促進作用を 有している ${ }^{13) 14)}$ 。また，FGF ファミリー(FGFs) のひ とつである KGF はラット Dunning 腫瘍3327におい て，上皮細胞に対して特異的な増殖促進作用が認めら れている15)。このように EGF，FGFs は前立腺におけ る主要な成長因子と考えられているが，今回得られた $\mathrm{PESVH}$ 細胞に対する $\mathrm{EGF}, \mathrm{FGFs}$ の増殖促進効果は 何れも強いものではなかった。この点に関して形質転 換した細胞では正常細胞に比べて各種の成長因子に対 する要求性が低下しており，この場合形質転換した細 胞自身が産生する成長因子によって増殖が刺激される 自己分泌機構が考えられている ${ }^{16)}$ そそこでノーザンブ ロット法による検討を行うと，PESVH 細胞では TGF- $\alpha$ とその受容体である EGFR，および TGF- $\beta 1$ と TGF- $\beta$ R2の mRNA の発現が認められた。

TGF- $\alpha$ についてみると，正常成熟ラット前立腺で は $\mathrm{EGF}$ とともに存在し ${ }^{11}$ ，幼若ラット前立腺にも免 疫組織学的に TGF- $\alpha$ および EGFR の存在が認めら れ，前立腺組織の発生，分化に TGF- $\alpha$ /EGFR の自己 分泌機構の関与が考えられている ${ }^{17)}$.一方, ヒトにおい ても多くの腫瘍組織や細胞株にその mRNA 発現が確 認されており，また同時に EGFRmRNAの発現も報 告されている ${ }^{18)}$.さらに, 前立腺腫瘍株においても，そ の増殖に対する TGF- $\alpha$ と EGFR の自己分泌機構の 関与が認められている ${ }^{19220)}$. 免疫組織学的に EGFR は ヒト正常前立腺組織にも認められるが，ヒト前立腺腫 瘍組織，特に内分泌療法抵抗性前立腺腫瘍においては EGFR と同時に TGF- $\alpha$ が正常組織に比較してょり強 く染色され, 前立腺癌細胞の増殖と自己分泌機構との 関連も考えられている ${ }^{21)}$. PESVH 細胞では TGF- $\alpha$ と EGFR の mRNA が発現していた。 今回は, 蛋白レ ベルでの解析を行っていないので断定は出来ないが, 
Fig. 4 Messenger RNA expression of growth factors and their receptors in PESVH cell.

Poly (A)RNA ( $2 \mu \mathrm{g} /$ lane) isolated from PESVH cell was electrophoresed and transferred to nylon membranes. The blots were hybridized to various probes (EGF, bFGF, KGF, TGF- $\alpha$, TGF- $\beta 1$, EGF receptor, FGF receptor 1 and TGF- $\beta$ receptor type II) labeled with digoxigenin, and the mRNAs were detected on $\mathrm{X}$-ray film as to chemiluminescence, as described under Methods. Glyceraldehyde-3-phosphate dehydrogenase (GAPDH) mRNA was used as control gene. Lane "C" : Poly (A)RNA isolated from PESVH cells cultured in the complete medium. Lane "T": Poly (A)RNA isolated from PESVH cells cultured in the complete medium plus testosterone $10^{-8} \mathrm{M}$. Lane "D": Poly(A) RNA isolated from PESVH cells cultured in the complete medium plus dihydrotestosterone $10^{-8} \mathrm{M}$.

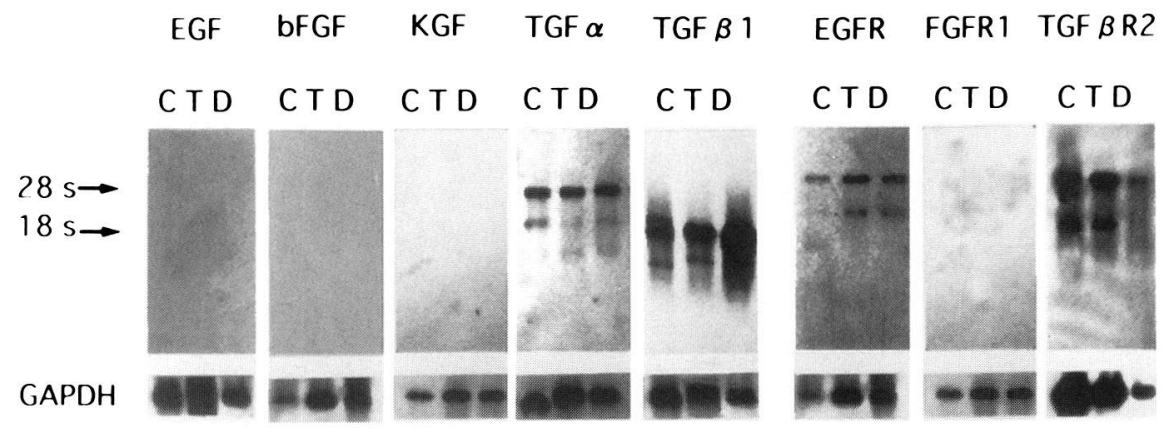

PESVH 細胞においてもTGF- $\alpha$ /EGFR の自己分泌 機構が存在し，外因性の成長因子に対する要求性が低 下している可能性がある。

TGF- $\beta$ は多彩な機能を有する成長因子であるが, 上 皮細胞に対しては一般に増殖抑制作用を示し ${ }^{22)}$, 正常 ラット前立腺においては去勢によって TGF- $\beta 1$ mRNAの発現が増強し，アポトーシスとの関連が考 えられている11). 一方, 種々の腫湯組織においても TGF- $\beta$ の存在が認められているが23), TGF- $\beta 1$ にる 細胞増殖抑制は一過性で, 常に TGF- $\beta 1$ にらされて いる細胞はその増殖抑制から逸脱している ${ }^{24)}$. また, ラット正常肝細胞では外因性 TGF- $\beta 1$ 濃度を段階的に 引き上げ, 持続的にさらすと, TGF- $\beta 1$ に対する感受性 が低下し，紐胞は癌化する ${ }^{25)}$.さらに, TGF- $\beta 10$ 過剩 発現は血管新生の促進, 細胞外マトリックスと間質の 支持，宿主免疫能への影響などの点から癌細胞に有利 な環境を作り出す26)など, TGF- $\beta 1$ は癌の進展に関与 すると考えられる. 今回検討したPESVH 細胞におい てはTGF- $\beta$ 受容体の mRNA は発現していたが，外 因性の TGF- $\beta 1$ にる増殖抑制はほとんどみられな かった。この細胞自身に TGF- $\beta 1 \mathrm{mRNA}$ も発現して いることから，自らの産生する TGF- $\beta 1$ に常にさらさ
れるためにその増殖抑制から逸脱した可能性も考えら れた。 また, TGF- $\beta 1 の$ 増殖抑制作用の発現には Rb 蛋 白の活性化が関与するとされている ${ }^{23)}$ が, SV400T 抗原はRb蛋白を不活化するためPESVH 細胞は TGF- $\beta 1$ の増殖抑制作用から逃れている可能性もあ る.

前立腺はアンドロゲンの標的臟器であるが, その作 用発現には成長因子の関与も考えられている ${ }^{27)}$. 去勢 ラットを用いた検討では前立腺背側葉における EGFmRNAの発現は去勢によって低下し，アンドロゲン 添加によって去勢前のレベルに回復する ${ }^{11}$.また, TGF- $\alpha$ mRNA の発現も EGF 同様アンドロゲン添加 によって増強する ${ }^{11}$. アンドロゲン依存性前立腺癌細 胞株である LNCaP は EGF, TGF- $\alpha$ を産生してい る ${ }^{28}$ が, さらにアンドロゲン反応性に EGF 受容体が 増加することによってアンドロゲンによる増殖促進効 果が発現する特徵が指摘されている ${ }^{29}$. また, アンドロ ゲン依存性マウス乳癌細胞株（SC-3）においてはテス トステロンが FGF 様成長因子の産生を促し, 自己の FGF 受容体に結合することによって自己分泌的に作 用する ${ }^{30)}$. 一方, 同様の乳癌細胞由来でアンドロゲン非 依存性の細胞株では, アンドロゲンによる刺激とは無 
関係に成長因子を産生し, 自己の増殖を促進する ${ }^{31}$. 今 回の PESVH 細胞においては TGF- $\alpha$ mRNA は, ア ンドロゲン添加と無関係に発現し，DNA 合成活性に ついてえられた成績に一致するとともに，本細胞にお けるアンドロゲン非依存性増殖の一つの機構と考えら れた。

前立腺細胞におけるアンドロゲン依存性の喪失は, 前立腺癌の治療を考える上でも重要な問題である．前 立腺癌に対するアンドロゲン除去療法は現在も治療の 主力を占めており, 約 $80 \%$ の前立腺癌が初期治療に反 応を示す.しかし, 半数以上の症例は初期治療後 $1 \sim 2$ 年で再燃し, 内分泌療法抵抗性となる。この過程で前 立腺癌細胞はアンドロゲン非依存性となるが，その機 序は未だ明らかではない.アンドロゲン非依存性前立 腺癌においては, アンドロゲン受容体遺伝子の点突然 変異も報告されているが, 機能的な受容体を有しなが ら非依存性となっている場合もある ${ }^{30)}$.また, 前述のア ンドロゲン誘導性成長因子の関与も考えられる。した がって, 内分泌療法抵抗性前立腺癌の治療を考える上 で, その基礎的検討としてのアンドロゲン非依存性細 胞の研究は重要な課題であり,アンドロゲン非依存性, かつ成長因子の産生能を有する本細胞株は有用な実験 モデルの一つになりうると考えた。

\section{結語}

SV40によって形質転換して得られたラット前立腺 背側葉由来上皮細胞株 (PESVH 細胞) の成長因子およ び成長因子受容体について検討し, 以下の結果を得た。

(1) PESVH 細胞では EGF, FGF 添加による細胞 増殖促進は最大で対照の 2.1 倍であり, 増殖促進効果は 弱かった。

(2) PESVH 細胞では TGF- $\beta 1$ 添加による増殖抑制 は認められなかった。

（3） $10^{-10} \sim 10^{-6} \mathrm{M} の \mathrm{~T} お$ よ $\mathrm{DHT}$ の添加は PESVH 細胞の増殖に影響を与えなかった.

(4) PESVH 細胞においてはTGF- $\alpha$, TGF- $\beta 1$, EGFR およびTGF- $\beta$ R2の mRNA がそれぞれ発現し ていた.

(5) PESVH 細胞はアンドロゲン非依存性前立腺細 胞として,一つの実験モデルになり得ると考えられた.

稿を終えるにあたり, 御指導, 御校閲を賜りました恩師碓 井 亞教授ならびに中原 満助教授に深謝いたします。さ らに, cDNA プローブを御提供いただき終始温かい御指導 を賜りました香川医科大学内分泌学教室 西望博士に 心から感謝いたします。
本論文の要旨は第65回日本内分泌学会総会, 第82回日本 泌尿器科学会総会㧍よび第67回日本内分泌学会秋季大会に おいて発表した。

\section{文献}

1) Manson, C.A. and Fischer, M.I. : Zinc content of the genital organs of the rat. Nature, 167, 859, 1951.

2) Matuo, Y., Nishi, N. and Wada, F.: Growth factors in the prostate. Arch. Androl., 19, 193210, 1987.

3) Dunning, W.F.: Prostate cancer in the rat. Natl. Cancer Inst. Monogr., 12, 351-369, 1963.

4) 中本貴久:前立腺上皮細胞の実験的研究. 第 1 編：ラット前立腺背側葉上皮細胞の初代培養法の 確立. 日泌尿会誌，79，87-95，1988.

5）中本貴久：前立腺上皮細胞の実験的研究. 第 2 編：ラット前立腺背側葉上皮の初代培養細胞の増 殖に対する性ホルモンおよび前立腺組織抽出液の 影響. 日泌尿会誌，79，96-103，1988.

6) Nishi, N., Matuo, Y., Nakamoto, T. and Wada, F. : Proliferation of epithelial cells derived from rat dorsolateral prostate in serum-free primary cell culture and their response to androgen. In Vitro Cell Dev. Biol., 24, 778-794, 1988.

7) Mckeehan, W.L. and Adams, P.S.: Heparinbinding growth factor/prostatropin attenuates inhibition of rat prostate tumor epithelial cell growth by transforming growth factor type $\beta$. In Vitro Cell Dev. Biol., 24, 243-246, 1988.

8) Mckeehan, W.L., Adams, P.S. and Rossner, M. P.: Direct mitogenic effects of insulin, epidermal growth factor, glucocorticoid, cholera toxin, unknown pituitary factors and possibly prolactin, but not androgen, on normal rat prostate epithelial cells in serum-free, primary cell culture. Cancer Res., 44, 1998-2010, 1984

9) Nakahara, M., Fukushima, M., Tacho, T., Usui, T. and Ide, T.: Establishment of a SV 40transformed cell line from primary culture of rat dorsolateral prostatic epiethelial cells. Exp. Cell Res., 190, 271-275, 1990.

10) Chomczynski, P. and Sacchi, N.: Single-step method of RNA isolation by acid guanidinium thiocyanate-phenol-chloroform extraction. Anal. Biochem., 162, 156-159, 1987.

11) Nishi, N., Oya, H., Matsumoto, K., Nakamura, T., Miyanaka, H. and Wada, F.: Changes in gene expression of growth factors and their receptors during castration-induced involution and androgen-induced regrowth of rat pros- 
tates. Prostate, 28, 139-152, 1996.

12) Jacobs, S.C., Pikna, D. and Lawson, P.K. : Prostatic osteoblastic factor. Invest. Urol., 17, 195-198, 1979.

13) Crabb, J.W., Armes, L.G., Carr, S.A., Johnson, C.M., Roberts, G.D., Bordoli, R.S. and McKeehan, W.L.: Complete primary structure of prostatropin, a prostate epithelial cell growth factor. Biochemistory, 25, 4988-4993, 1986.

14) Gospodarowicz, D., Neufeld, D. and Schweegerer, L.: Fibroblast growth factor: Structure and biological properties. J. Cell Physiol., 5, 15 -26, 1987.

15) Yan, G., Fukabori, Y., Nikolaropoulos, S., Wan, F. and McKeehan, W.L.: Heparin-binding keratinocyte growth factor is a candidate stromal to epithelial cell andromedin. Mol. Endocr., 6, 2123-2128, 1992.

16) Sporn, M.B. and Todaro, G.J.: Autocrine secretion and malignant transformation of cells. N. Engl. J. Med., 303, 878-880, 1980.

17) Taylor, T.B. and Ramsdell, J.S.: Transforming growth factor- $\alpha$ and its receptor are expressed in the epithelium of the rat prostate gland. Endocrinology, 133, 1306-1311, 1993.

18) Derynck, R., Goeddel, D.V., Ullrich, A., Gutterman, J.U., Williams, R.D., Bringman, T.S. and Berger, W.H.: Synthesis of messenger RNAs for transforming growth factors $\alpha$ and $\beta$ and the epidermal growth factor recepter by human tumors. Cancer Res., 47, 707-712, 1987.

19) Wilding, G., Valverius, E., Knabb, C. and Gelmann, E.P.: Role of transforming growth factor- $\alpha$ in human prostate cancer cell growth. Prostate, 15, 1-12, 1989.

20) Hofer, D.R., Sherwood, E.R., Bromberg, W.D., Mendelsohn, J., Lee, C. and Kozlowski, J.M. : Autonomous growth of androgen-independent human prostatic carcinoma cell : Role of transforming growth factor $\alpha$. Cancer Res., 51, 2780 $-2785,1991$.

21) Cohen, D.W., Simak, R., Fair, W.R., Melamd, J., Scher, H.I. and Cordon-Cardo, C.: Expression of transforming growth factor- $\alpha$ and the epider- mal growth factor receptor in human prostate tissues. J. Urol., 152, 2120-2124, 1994.

22) Sporn, M.B., Roberts, A.B., Wakefield, L.M. and Assolian, R.K.: Transforming growth factor$\beta$ : Biological function and chemical structure. Sicence, 233, 532-534, 1986.

23) Moses, H.L., Yang, E.Y. and Pietenpol, J.A. : TGF- $\beta$ stimulation and inhibition of cell proliferation: New mechanistic insights. Cell, 63, 245 -247, 1990.

24) Steiner, M.S. and Barrack, E.R.: Transforming growth factor- $\beta 1$ overproduction in prostate cancer: Effect on growth in vivo and in vitro. Mol. Endocr., 6, 15-25, 1992.

25) Zhang, X., Wang, T., Batist, G. and Tsao, M.S. : Transforming growth factor $\beta 1$ promotes spontaneous transformation of cultured rat liver epithelial cells. Cancer Res., 54, 6122, 1994.

26) Massague, J.: The transforming growth factor $\beta$ family. Ann. Rev. Cell. Biol., 6, 597, 1990.

27) Nishi, N., Matuo, Y. and Wada, F.: Comparative analysis of growth factors in normal and pathologic human prostate. Prostate, 13, 3948, 1988.

28) Connolly, J.M. and Rose, D.P. : Production of epidermal growth factor and transforming growth factor-alpha by the androgenresponsive $\mathrm{LNCaP}$ human prostate cancer cell line. Prostate, 16, 209-218, 1990.

29) Schuurmans, E.P., Bolt, J. and Mulder, E. : Androgens stimulate both growth rate and epidermal growth factor receptor activity of the human prostate tumor cell LNCaP. Prostate, 12, 55-63, 1988.

30) Nonomura, N., Lu, J., Tanaka, A., Yamanishi, H., Sato, B., Sonoda, T. and Matsumoto, K. : Interaction of androgen-induced autocrine heparin binding growth factor with fibroblast growth factor receptor on androgen-dependent shionogi carcinoma 115 cells. Cancer Res., 50, 2316-2321, 1990.

31）佐藤直秀, 鈴木啓悦, 島崎 淳 : アンドロゲン依存 性喪失の機構. Human Cell, 6, 170-175, 1993. (1997年 2 月 20 日受付， 9 月 4 日受理) 